\title{
THE INVOLVEMENT OF GIBBERELLINS IN PHYTOCHROME-CONTROLLED FLOWERING OF PHARBITIS NIL
}

\author{
HALINA KULIKOWSKA-GULEWSKA, JAN KOPCEWICZ \\ Department of Plant Physiology and Morphogenesis \\ Institute of General and Molecular Biology, Nicholas Copernicus University \\ Gagarina 9, 87-100 Toruń, Poland \\ e-mail: hkgulews@biol.uni.torun.pl
}

(Received: July 12, 2001. Accepted: November 12, 2001)

\begin{abstract}
The seedlings of Pharbitis nil, a sesitive short-day plant (SDP), were cultivated under special photoperiodic conditions: 72-h-long darkness, 24-h-long white light with low intensity, 24-h-long inductive night. During 24-h-long inductive darkness the total content of gibberellins in cotyledons underwent fluctuations with a maximum at $0 \mathrm{~h}$ and $8 \mathrm{~h}$, and a decrease at the end of the dark period. FR light applied at the end of the 24-h-long white-light period inhibited flowering. $\mathrm{R}$ light flash and partially exogenous $\mathrm{GA}_{3}$ added on cotyledons could reverse the effect of FR. The seedling growth was not affected by FR and R light irradiation, but was promoted by exogenous $\mathrm{GA}_{3}$ application. The obtained results suggest that gibberellins are involved in photoperiodic control of SDP $P$. nil flowering. This involvement has nothing in common with participation of gibberellins in the control of the elongation growth of seedlings.
\end{abstract}

KEY WORDS: flowering, gibberellins, Pharbitis nil.

\section{INTRODUCTION}

Gibberellins have a significant influence on flowering of photoperiodically sensitive plants (Metzger 1990). Pharbitis nil is a sensitive short-day plant (SDP) which flowers when 4-5-day old seedlings undergo 16-h-long inductive night. Seedlings cultivated in continuous light remain vegetative. Exogenous $\mathrm{GA}_{3}$ application on subinductive 12-h-long photoperiod can slightly stimulate flowering. However $\mathrm{GA}_{3}$ application during 16-h-long fully inductive night has no influence on flowering (Kulikowska-Gulewska et al. 2000).

Reactions induced by red (R) and far-red (FR) light are mediated by phytochrome. This chromoprotein occurs in two molecular forms, with different spectral properties and biological functions: Pr form with absorption maximum within red light (about $660 \mathrm{~nm}$ ) and Pfr absorbing far-red light (about $730 \mathrm{~nm}$ ). Pfr is the active phytochrome form (Furuya 1987; Quail 1994). Pfr occurs in two pools: labile (Phy A, PfrA) and stable (Phy B, Pfr B). Phy B is much more stable in light than Phy A, with a half-life more than 12 hours.

\footnotetext{
Abbreviations

CCC - 2-chloroethyltrimethylammonium chloride; FR - far-red light; $\mathrm{GA}_{\mathrm{n}}$ - gibberellin $\mathrm{n} ; \mathrm{R}$ - red light; SDP - short-day plant; LDP - long-day plant, $P$. nil-Pharbitis nil
}

Studies on the mechanism of photoperiodic flower induction should be conducted under conditions enabling the proper functioning of one phytochrome fraction, the stable or labile one (Thomas 1991; Cymerski and Kopcewicz 1994, 1995). We obtained such an experimental system using different methods of seedling cultivation. Such a system is as follows: 72-h-long dark period, 24-h-long period of low intensity white light and 24-h-long inductive night. Under such conditions the seedlings enter the inductive $24 \mathrm{~h}$ night with incomplete processes dependent on stable phytochrome (Cymerski and Kopcewicz 1994). As a result of this kind induction seedlings produced 4-5 flower buds.

The aim of the present work was to investigate the content of endogenous gibberellins and the influence of FR, $R$ and exogenous $\mathrm{GA}_{3}$ application on $P$. nil flowering under a specific photoperiod regime.

\section{MATERIAL AND METHODS}

\section{Plant Material}

Seeds of $P$. nil Chois. cv Violet (Marutane Seed Co., Kyoto, Japan) were scarified with a scalpel and imbibed for $24 \mathrm{~h}$ in distilled water $\left(25^{\circ} \mathrm{C}\right)$. The swollen seeds were sown into pots filled with perlite: sterile sand (2:1). There 
were 15 seeds in each pot. The pots were transferred to a growth chamber at $25^{\circ} \mathrm{C}$ with darkness for 72 hours. After steeping they were irradiated with low intensity white light $\left(6 \mathrm{~W} \mathrm{~m}^{-2}\right)$ for $24 \mathrm{~h}$ followed by a 24 -h-long inductive dark period.

Plant material was harvested at the 72 nd hour of darkness, every 4 hours during 24-h-long low intensity white light and during 24-h-long inductive night. Plants were cut into cotyledons, hypocotyls and roots, frozen and stored until analysis.

In some experiments the seedlings were irradiated with a 15 -min-long pulse of far-red (FR) light $\left(\gamma_{\max }=730 \mathrm{~nm}\right.$, $\gamma_{1 / 2}=7 \mathrm{~nm}$, intensity $4.3 \mu \mathrm{W} / \mathrm{cm}^{2}$ ) at the end of the $24-\mathrm{h}$ -long white light period. The effect of FR photoreversibility by red (R) light was also studied. Exogenous GA, ( $1 \mathrm{mM})$ was applied to the cotyledons $(100 \mu \mathrm{l}$ per plant) 7 times using a soft brush during 24-h-long inductive darkness (at $0,4,8,12,16,20$ and $24 \mathrm{~h}$ ).

After the completion of treatments the plants were grown in a growth chamber under continuous light at $25^{\circ} \mathrm{C}$ for 14 days. The number of flower buds per plant was then determined using a dissection microscope. Also at that time, the elongation growth of treated plants was measured. Fifteen plants were used in each experiment, which was repeated at least 3 times.

\section{Determination of endogenous GAs}

GAs were extracted from frozen plant material (2 $\mathrm{g}$ of cotyledons, hypocotyls or roots per sample) by $80 \%$ methanol (2 parts of $25 \mathrm{ml}$ each), fractionated and purified according to the method described by Hedden (1987). After filtration the extract was passed through a Baker bond spe octadecyl C - 18 column (J.T. Baker, S. Witko Eurocolor, Łódź, Poland) loaded as follows: $5 \mathrm{ml}$ of $80 \%$ methanol, $5 \mathrm{ml}$ of $5 \%$ acetic acid, $50 \mathrm{ml}$ of plant extract, 5 $\mathrm{ml}$ of $5 \%$ acetic acid, $5 \mathrm{ml}$ of distilled water and $1.2 \mathrm{ml}$ of $100 \%$ methanol. The last fraction $(1.2 \mathrm{ml}$ of methanol eluates) was used in thin layer chromatography (TLC) on aluminium foil (Kavalier, Czech Republic) covered with silica gel. The solvent system was acetic acid - chlorophorm ethyl acetate $(5: 90: 10 \mathrm{v} / \mathrm{v})$. Gibberellins showed activity in four $\mathrm{R}_{\mathrm{f}}$ zones: $0.0-0.2,0.3-0.5,0.6-0.8$ and $0.9-1.0$. P nil extracts were analysed for GA biological activity by the lettuce hypocotyl test (Frankland and Wareing 1960). Extracts were also analysed by Shimadzu GC - 14 B equipped with a capillary column according to the method of Jolliffe et al. (1979) and Kulikowska-Gulewska et al. (2000). The results were statistically evaluated and LSD was calculated at a significance level of 0.01 and 0.05 .

\section{RESULTS}

\section{Endogenous GA level in cotyledon, hypocotyl and root}

During 24-h-long inductive night the total content of gibberellins in cotyledons underwent fluctuations with a maximum at $0 \mathrm{~h}$ and $8 \mathrm{~h}$ of darkness and a decrease during the second half of inductive night (Fig. 1). In hypocotyls maximal content of these substances was observed at the $0 \mathrm{~h}$ and $12 \mathrm{~h}$ of darkness, and in roots there was successive increase of GAs which could suggest transport of gibberellins from cotyledons to hypocotyls and roots, as the cotyledons did not show any gibberellin - like activity at $12 \mathrm{~h}$ of dark-

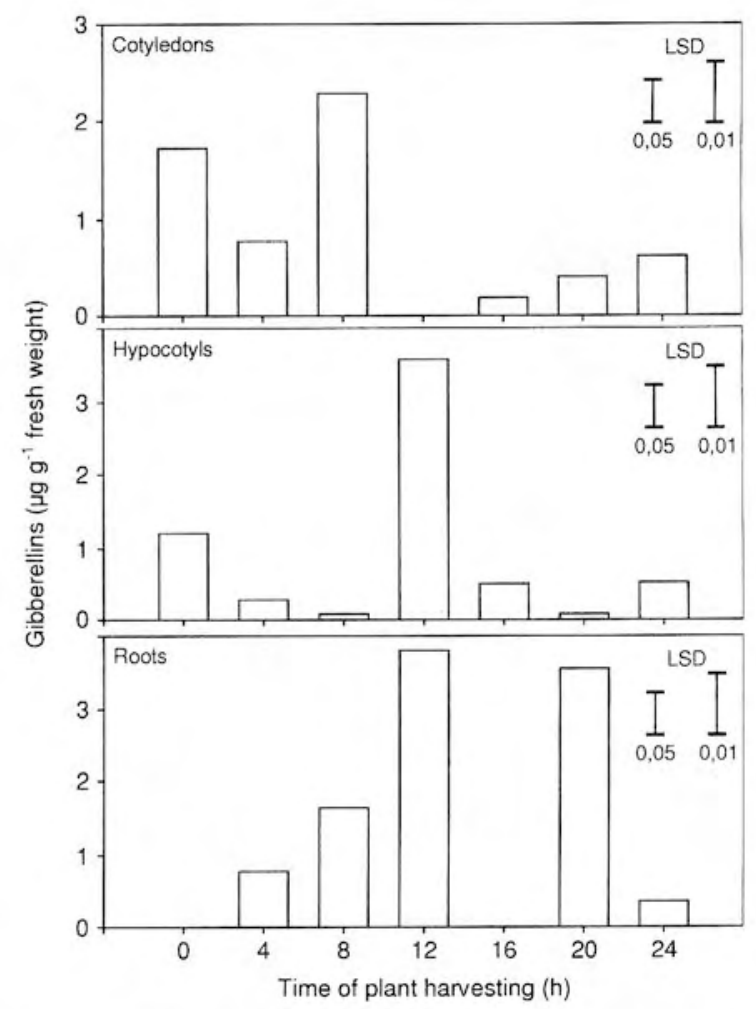

Fig. 1. Gibberellin $\left(\mathrm{GA}_{1}, \mathrm{GA}_{3}, \mathrm{GA}_{4}, \mathrm{GA}_{7}\right)$ content in cotyledons, hypocotyls and roots of Pharbitis nil during 24-h-long inductive night.

ness. During the second half of inductive night gibberellin content in hypocotyls was rather small. In roots increase at the $20^{\text {th }}$ hour of darkness and then decrease in these compounds was observed. Generally, a $P$. nil seedling ends the inductive night with a low endogenous gibberellin level, amounting to about $0.5 \mu \mathrm{g} \mathrm{f.w.-1}$ (Fig. 1).

\section{Effects of photoperiod, $\mathrm{GA}_{3}$ and FR light on flowering and elongation growth}

Far-red light applied at the end of the 24-h-long period of white light with low intensity inhibited flowering of $P$. nil seedlings. Control plants formed about 5 floral buds and FR treated ones 0.6 (Fig. 2A). Terminal flowering was reduced by FR treatment from $100 \%$ in control plants to less than $20 \%$ in the treated ones (Fig. 2B). Red light applied immediately after FR light pulse could reverse the effect of FR irradiation (Fig. 2A and B). Seedling shoot length was not influenced by FR and R irradiations (Fig. 3).

$\mathrm{GA}_{3}$ applied to the cotyledons of FR treated plants could partially reverse the inhibitory effect of FR light on flowering. Control plants formed 4.2 floral buds per plant. A pulse of FR light resulted in 0.35 floral buds per plant only (Fig. 4A). Terminal flowering was reduced from $75 \%$ for the control to less than $10 \%$ for FR treated plants (Fig 4B). Exogenous $\mathrm{GA}_{3}$ application reversed partially this inhibitory effect of FR, especially at the end of a dark period (Fig. $4 \mathrm{~A}$ and $\mathrm{B}$ ). However restoring flowering to the control level was impossible.

The ability of exogenous $\mathrm{GA}_{3}$ to reverse inhibitory FR influence at $0 \mathrm{~h}$ and $8 \mathrm{~h}$ was coincident with an increased endogenous GAs level in cotyledons of $P$. nil seedlings (Fig. 1). At the end of inductive night exogenous $\mathrm{GA}_{3}$ was still effective even though the endogenous GAs level was 


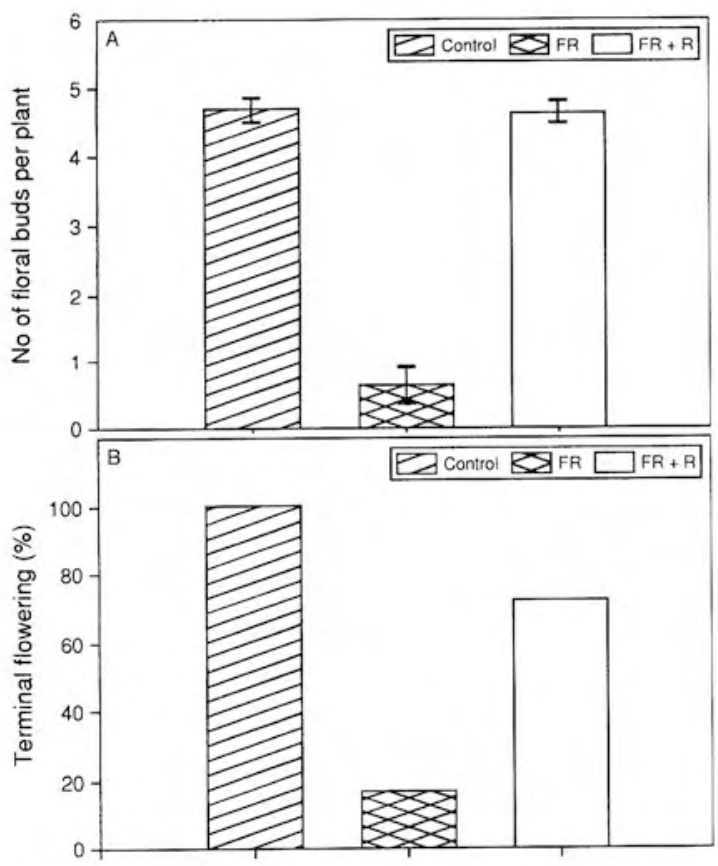

Fig. 2. Effect of far-red (FR) and red (R) light on Pharbitis nil flowering. A - number of floral buds per plant, B - terminal flowering. Values are means $\pm \operatorname{SE}(n=45)$.

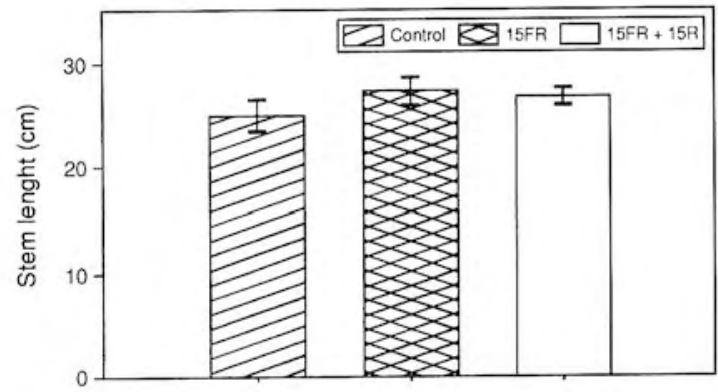

Fig. 3. The influence of far-red (FR) and red (R) light impulse on mean shoot length of Pharbitis nil. Values are means $\pm S E(n=45)$.

low. Exogenous $\mathrm{GA}_{3}$ applied during the 24-h-long dark period could stimulate seedling growth above the control level (Fig. 5).

\section{DISCUSSION}

Endogenous gibberellin content was studied in cotyledons, hypocotyls and roots of Pharbitis nil seedlings during 24-h-long inductive night. Plant material was harvested every 4 hours. $P$. nil cotyledons contained a relatively high level of gibberellins at $0 \mathrm{~h}$ and $8 \mathrm{~h}$ of inductive night. The second half of darkness was accompanied by a decrease in the content of these substances. Similar results were reported earlier for seedlings which underwent 16-h-long inductive night (Kulikowska-Gulewska et al. 2000). The low level of gibberellins after 24-h-long inductive night can be a prerequisite of entering reproductive growth stage. Similar results were obtained by Zeevaart (1964) who induced $P$. nil seedling flowering under continuous light (noninductive conditions) using CCC, gibberellin biosynthesis inhibitor. Oden and Heide (1989) reported a rapid decrease in gibberellin content in Begonia when the plants

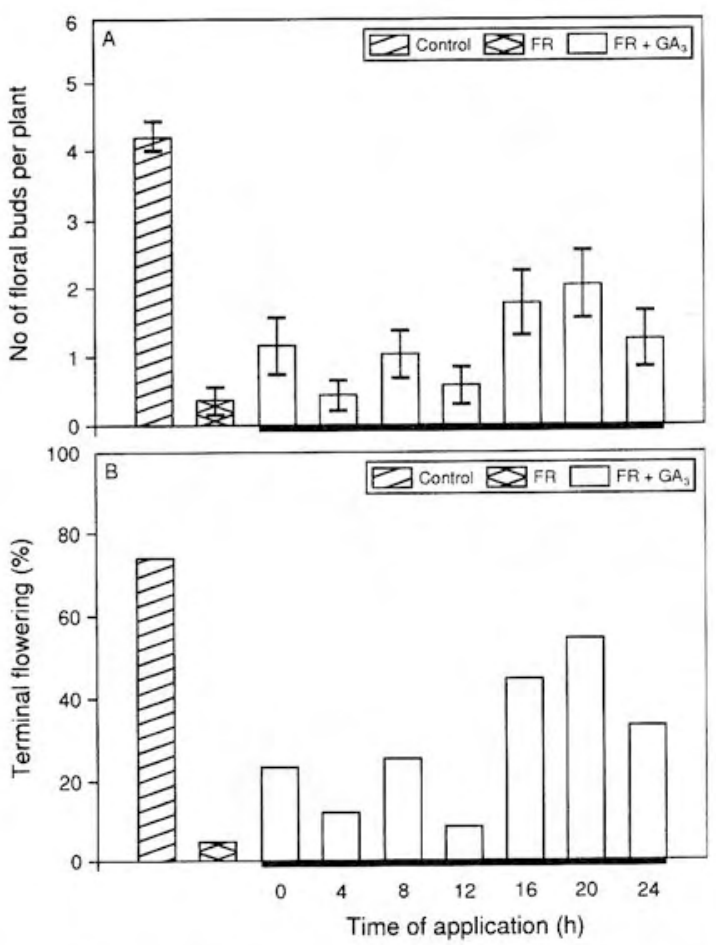

Fig. 4. Effect of end-of-day irradiation of far-red (FR) light and $\mathrm{GA}_{3}$ application on flowering of Pharbitis nil plants. $\mathrm{GA}_{3}\left(10^{-3}\right.$ $\mathrm{M}, 100 \mu \mathrm{l})$ was applied to cotyledons seven times during the 24h-long inductive night $(0,4,8,12,16,20,24 \mathrm{~h})$. Values are means \pm SE $(n=45)$. Control plants $(72 \mathrm{~h}$ in darkness $+24 \mathrm{~h}$ in white light with lowered intensity +24 -h-long inductive night). FR - treated plants $(72 \mathrm{~h}$ in darkness $+23 \mathrm{~h} 45 \mathrm{~min}$ in white light with lowered intensity $+15 \mathrm{~min} F R+24 \mathrm{~h}$ inductive night). A number of floral buds per plant, B - terminal flowering. Values are means $\pm S E(n=45)$.

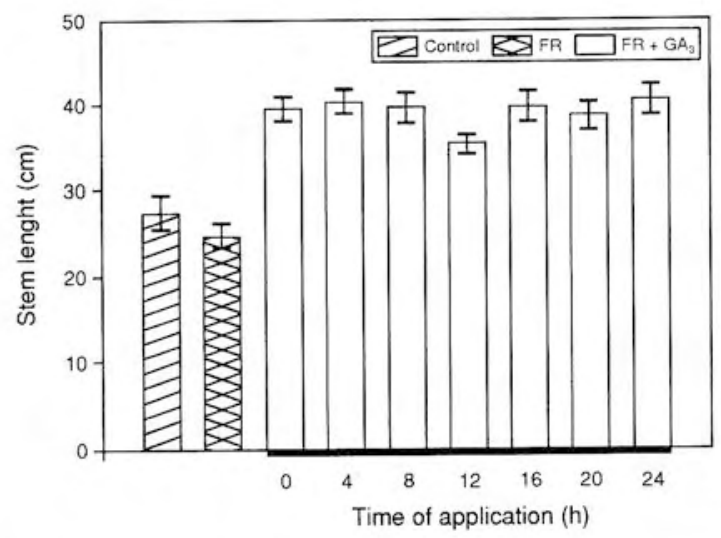

Fig. 5. Effect of far-red (FR) light irradiation (before inductive night) and $\mathrm{GA}_{3}$ application (during inductive night) on mean shoot length of Pharbitis nil. Values are means \pm SE $(n=45)$.

were transferred from noninductive flowering conditions to inductive ones.

Endogenous gibberellin content was high in hypocotyls and roots of $P$. nil seedlings at $12 \mathrm{~h}$ of 24 -h-long inductive night. One can assume transport of these hormones from cotyledons to hypocotyls and roots because at the same time no gibberellin activity in cotyledons was observed. Yang and coworkers (1996) also suggested endogenous gibberellin translocation from cotyledons to hypocotyls and roots. 
On the other hand, endogenous gibberellin content in phloem exudates and cotyledons of $P$. nil seedlings under inductive and noninductive conditions indicated that the level of these substances was higher under inductive conditions (Wijayanti et al. 1995). Differences in the GAs content in different plant parts can reflect differential biosynthetic regulation, transformation or translocation of GAs (Olsen et al. 1995).

Previously, we have shown that studies on the mechanism of photoperiodic flower induction should be conducted under the conditions enabling the functioning of only one phytochrome system - stable or labile (Cymerski, Kopcewicz 1994, 1995). We have found that far-red light applied at the end of the light phase inhibits the flowering of $P$. nil. It should be noticed, however, that far-red light does not exert any influence, or the effect is only very slight, if the light phase of the photoperiod is too long, and the light is of high intensity. The most pronounced effect of far-red light on flowering was obtained when $P$. nil seedlings were grown 72 hrs in darkness, 24 hrs in white light with lowered intensity (day) and then were treated with 24-h-long inductive night. Under such conditions the seedlings enter the inductive 24-h-long night with unfinished processes dependent on stable phytochrome (Cymerski, Kopcewicz 1995). The irradiation at the end of the day with the impulse of far-red light causes the blockade of stable phytochrome - controlled reactions and the inhibition of flowering. In such experimental conditions it has been stated that red light and partially $\mathrm{GA}_{3}$ could reverse the inhibition of flowering caused by far-red light. Because it seems very probable that red light could promote the endogenous content of gibberellins (Black, Vlitos 1972) it means that gibberellins are taking part in the phytochrome - regulated mechanism of flower induction in $P$. nil.

Pfr B is stable in darkness and can act in the control of flowering for several hours. Furuya and Schäfer (1996) suggested involvement of Phy B and some Phy X in the photoperiodic control of flowering.

Red and far - red light irradiation did not affect $P$. nil seedling shoot length (Fig. 3). Similar results were obtained for Chenopodium album (Kopcewicz et al. 1992).

Exogenous $\mathrm{GA}_{3}$ applied to $P$. nil cotyledons, treated with FR light, could partly reverse the inhibitory FR effect on flowering. $\mathrm{GA}_{3}$ ability to reverse the inhibitory effect of FR on $P$. nil flowering is coincident with an increased endogenous gibberellin level at $0 \mathrm{~h}$ and $8 \mathrm{~h}$ of inductive night. However during the second half of 24-h-long inductive night $\mathrm{GA}_{3}$ was still effective, although the endogenous GAs level was low. Endogenous gibberellin content in $P$. nil tissue after $\mathrm{R}$ and FR light treatment are under the investigations in our laboratory. Several reports stated that exogenous $\mathrm{GA}_{3}$ applied immediately before inductive night could stimulate flowering (Ingram and Browning 1979; King et al. 1987; Simmons and Coulter 1979).

Far-red light irradiation had no significant influence on $P$. nil seedling shoot length. End-of-day FR light irradiation usually affects hypocotyl elongation. On the other hand phyB deficient mutants show reduced sensitivity to end-of-day FR irradiation (McNellis and Deng 1995). Under our experimental conditions (72-h-long darkness, 24-h-long white light with lowered intensity, 24-h-long darkness) stable phytochrome-dependent processes were also incomplete.
GAs applied to cotyledons every $4 \mathrm{~h}$ during 24-h-long inductive night, following FR treatment, clearly stimulated shoot growth. Ogawa et al. (1990) also reported stem growth stimulation by GAs application. Similar results were obtained for Lolium temulentum (Evans 1990). High seedlings of $P$. nil var. Tendan contained higher amounts of endogenous GAs than the dwarf variety Kidachi (Ogawa 1965). Olsen et al. (1995) found that gibberellins affected Salix pentandra seedling growth, but photoperiod had no influence on gibberellin metabolism.

Generally it seems that the obtained results show that gibberellins are specifically involved in phytochrome controlled $P$. nil transition to flowering. This is an independent phenomenon from the widely known effect of gibberellins on plant elongation growth.

\section{ACKNOWLEDGEMENTS}

This research was supported by grant No 6PO4C 05616 from the National Commitee for Scientific Research (KBN).

\section{LITERATURE CITED}

BLACK M., VLITOS A.J. 1972. Possible interrelationships of phytochrome and plant hormones. Phytochrome. Mitrakos K (ed.), Shropshire Academic Press, London and New York: 18-523.

CYMERSKI M., KOPCEWICZ J. 1994. Labile phytochrome and photoperiodic flower induction in Pharbitis nil Chois. The irreversible phytochrome hypothesis. Acta Soc. Bot. Pol. 63: 75-279.

CYMERSKI M., KOPCEWICZ J. 1995. KCN blocks the inhibiting effect of red light night - break on flowering of Pharbitis nil. J. Plant Physiol. 145: 189-190.

EVANS L.T., KING R.W., CHU A., MANDER L.N., PHARIS R.P. 1990. Gibberellin structure and florigenic activity in Lolium temulentum, long-day plant. Planta 182: 97-106..

FRANKLAND B., WAREING P.F. 1960. Effect of gibberelic acid on hypocotyl growth of lettuce seedlings. Nature 185: 255-256.

FURUYA M. 1987. Phytochrome anf photoregulation in plants. Academic Press, Tokyo.

FURUYA M., SCHÄFER E.B. 1996. Photoperception and signalling of induction reactions by different phytochromes. Elsevier Trends Journals, Vol. 1, No. 9: 301-307.

HEDDEN P. 1987. Gibberellins. In: Principles and Practise of Plant Hormone Analysis. Vol. 1. Rivier L, Crozier A. (eds), Academic Press, New York, NY: 26-27.

INGRAM T.I., BROWNING G. 1979. Influence of the photoperiod on seed development in the genetic line of peas GA and its relation to changes in endogenous gibberellins measured by combined gas - chromatography - mass spectrometry. Planta 146: 423-432.

JOLLIFFE V.A., COGGINS C.W., JONES W.W. 1979. Silylation technique for plant growth regulators. J. Chromatogr. 179: 333-336.

KING R.W., PHARIS R.P., MANDER Z.N. 1987. Gibberellins in relation to growth and flowering in Pharbitis nil Chois. Plant Physiol. 84: 1126-1131.

KOPCEWICZ J., TRETYN A., CYMERSKI M. 1992. Fitochrom i morfogeneza roślin. PWN Warszawa. (in Polish)

KULIKOWSKA-GULEWSKA H., MAJEWSKA M., KOPCEWICZ J. 2000. Gibberellins in the control of photoperiodic flower transition in Pharbitis nil. Physiol Plant 108: 202-207. 
MCNELLIS T.M., DENG X.W. 1995. Light control of seedling morphogenetic pattern. The Plant Cell 7: 1749-1761.

METZGER J.D. 1988. Gibberellins and flower initiation in herbaceous angiosperms. In: Pharis R.P. and Roods S.B. (eds) Plant Growth Substances, Springer Verlag, Berlin, Heidelberg: 476-485.

ODEN P.CH., HEIDE O.M. 1989. Quantitation of gibberellins and indolacetic acid in Begonia leaves: Relationship with environment regeneration and flowering. Physiol. Plant. 76: 50)-506.

OGAWA Y. 1965. Changes in amount of gibberellin - like substances in the seedling of Pharbitis nil with special reference to expansion of cotyledons. Plant and Cell Physiol. 5: 11-20.

OLSEN J.E., JENSEN E., JUNTILLA O., MORITZ T. 1995. Photoperiodic control of endogenous gibberellins in seedlings of Salix pentandra. Physiol. Plant. 93: 639-644.

QUAIL P.H. 1994. Phytochrome genes and their expression. In: Photomorphogenesis in Plants. Kendrick R.F., Kronenberg GHM (eds) Kluwer Acad. Publ., Dordrecht: 71-104.
SIMMONS H.A., COULTER M.W. 1979. Responses of normal and dwarf Pharbitis nil to an extended dark period gibberellic acid. Plant Cell Physiol. 20: 1671-1673.

THOMAS B. 1991. Phytochrome and photoperiodic induction. Physiol. Plant. 81: 571-577.

VINCE PRUE D., GRESSEL J. 1985. Pharbitis nil. In: Halevy AH (ed) Handbook of Flowering. Vol. IV, CRC Press, Boca Raton. Fl: 47-81.

WIJAYANTI L., KOBAYASHI M., FUJIOKA S., YOSHIZAWA K., SAKURAI A. 1995. Identification and quantification of abscisic acid, indole-3-acetic acid and gibberelins in phloem exudates of Pharbitis nil. Biosci. Biotech. Biochem. 59: 1533-1535.

YANG Y., YAMAGUSHI J., MYROFUSHI N. 1996. Metabolism and translocation of gibberellins in the seedlings of Pharbitis nil (II). Photoperiodic effect on metabolism and translocation of gibberellins applied to cotyledons. Plant Cell Physiol. 37: 69-75.

ZEEVAART J.A.D. 1964. Effect of the growth retardant CCC on floral initiation and growth in Pharbitis nil. Plant Physiol. 39: $402-408$.

\section{GIBERELINY \\ W FITOCHROMOWEJ KONTROLI KWITNIENIA PHARBITIS NIL}

\section{STRESZCZENIE}

Siewki Pharbitis nil uprawiano w specjalnych warunkach fotoperiodycznych: 72-godzinny okres ciemności, 24 -godzinny okres światła białego o niskiej intensywności, 24-godzinna indukcyjna noc. W powyższych warunkach siewki rozpoczynają $24 \mathrm{~h}$ noc indukcyjną z niezakończonymi procesami zależnymi od fitochromu stabilnego.

W liścieniach, hipokotylach i korzeniach siewek Pharbitis nil badano zawartość endogennych giberelin za pomocą chromatografii gazowej i biotestu hipokotyla sałaty. Podczas 24-godzinnej indukcyjnej nocy, całkowita Zawartość giberelin w liścieniach ulegała wahaniom, z maksimum w 0 godz. i 8 godz. nocy i malała pod koniec okresu ciemnego. Światło dalekiej czerwieni (FR) zaaplikowane na koniec 24-godzinnego okresu światła białego o obniżonej intensywności hamowało kwitnienie. Światło czerwone (R) i częściowo egzogenna $\mathrm{GA}_{3}$ odwracały hamujący wpływ FR. Światło R i FR nie wpływało na wzrost siewek, natomiast wzrost ich był pobudzany przez dodanie egzogennej $\mathrm{GA}_{3}$.

Otrzymane wyniki sugerują udział giberelin w fotoperiodycznej kontroli kwitnienia SDP Pharbitis nil. Przypuszcza siẹ, że udział giberelin w kontroli wzrostu elongacyjnego siewek odbywa się poprzez inny szlak metaboliczny niż kontrola kwitnienia.

SŁOWA KLUCZOWE: kwitnienie, gibereliny, Pharbitis nil. 